Volume 1 Issue 1, March 2017: pp. 64-74. Copyright (c) 2017 HOLREV. Faculty of Law, Halu Oleo University, Kendari, Southeast Sulawesi, Indonesia. ISSN: 2548-1762 I e-ISSN: 2548-1754. Open Access at: http://ojs.uho.ac.id/index.php/holrev/

Halu Oleo Law Review is licensed under a Creative Commons Attribution 4.0 International License, which permits unrestricted use, distribution, and reproduction in any medium, provided the original work is properly cited.

\title{
Reposisi Eksekutif Review Terhadap Peraturan Daerah dalam Kerangka Otonomi Daerah
}

\author{
Review of Executive Re-position toward Local \\ Ordinance in the Context of Local Autonomy
}

Muhammad Junaidi

Universitas Semarang

E-mail: institut.junaidi@gmail.com

\begin{abstract}
The executive authority to run the executive review becomes one of the most significant contradictions to the paradigm of local governance implementation as set forth in Act No. 23 year 2014 on local governance. On the one hand, the executives need the executive review authority in harmonizing the policy of the central government and local government, but on the other side in the doctrine of power separation of testing the local regulations is the authority of the judicial institutions in the Constitution of the Republic of Indonesia which mandate is run by the Supreme Court. Based on these conditions, it is possible to conduct executive review conducted not only by the President, but still pay attention to the approval of the Supreme Court. It is hoped that such reposition will promote the harmonization and synchronization of legislation efforts.
\end{abstract}

Keywords: executive review; regulation; autonomy.

\begin{abstract}
Abstrak: Kewenangan eksekutif menjalankan eksekutif review menjadi salah satu pertentangan yang berarti terhadap paradigma implementasi pemerintahan daerah yang tertuang dalam Undang-Undang Nomor 23 tahun 2014 tentang pemerintahan daerah. Di satu sisi, eksekutif membutuhkan kewenangan eksekutif review dalam mengharmonisasikan kebijakan antara pemerintahan pusat dengan pemerintah daerah, akan tetapi disisi lain dalam doktrin pemisahan kekuasaan pengujian Peraturan-peraturan daerah merupakan wewenang dari lembaga yudikatif yang dalam Undang-Undang Dasar Negara Republik Indonesia amanatnya dijalankan oleh Mahkamah Agung. Berangkat dari kondisi tersebut maka memungkinkan dilakukannya eksekutif review dilakukan bukan hanya oleh Presiden, akan tetapi tetap memperhatikan persetujuan Mahkamah Agung. Diharapkan melalui reposisi yang demikian akan mengedepankan upaya harmonisasi dan sinkronisasi peraturan perundang-undangan.
\end{abstract}

Keywords: eksekutif review; peraturan; otonomi 


\section{PENDAHULUAN}

Dalam amanat Undang-Undang Dasar Negara Republik Indonesia tahun 1945 dinyatakan pada Pasal 1 ayat 1 bahwa Negara Indonesia adalah Negara kesatuan berbentuk Republik. Falsafah Negara kesatuan berbentuk Republik tersebut bahkan dipertegas kembali dalam Pasal 37 Ayat 5 yang tidak boleh diubah (diamendemen).

Makna yang kemudian ditemukan dalam doktrin konstitusi tersebut jelas bahwa sistem Negara kesatuan menjadi nilai yang tidak bisa ditawar-tawar. Pandangan inilah yang kemudian juga menjadi dasar dari sistem pemerintah yang dibangun pasca reformasi yang sebelumnya menerapkan konsep sentralisasi kemudian berganti menjadi desentralisasi. Hal ini salah satunya yang dituangkan dalam Undang-Undang Republik Indonesia Nomor 9 Tahun 2015 tentang Perubahan Kedua Atas Undang-Undang Nomor 23 Tahun 2014 tentang Pemerintahan Daerah.

Meski telah dilakukan perubahan secara mendasar dari sistem sentralisasi, dimana kebijakan pemerintahan daerah dibentuk berdasarkan konsep yang didesain oleh pemerintah pusat menjadi desentralisasi yang berdasarkan pada model partisipasi dan aspirasi masyarakat daerah, akan tetapi polemik implementasi pemerintah daerah masih tetap menjadi persoalan yang terus berkembang di era kesadaran akan demokrasi semakin nyata seperti sekarang ini. Selain persoalan structural (aparatur) dan cultural (budaya masyarakat), masalah utama yang tidak kalah pelik adalah substansi atau peraturan perundang-undangan yang acapkali tidak konsisten terhadap konstitusi.

Jika kembali pada orientasi pemerintahan daerah secara umum, ada tiga tujuan yang harus dicapai dalam penyelenggaraan pemerintah daerah untuk menciptakan pemberdayaan daerah dan masyarakatnya. Pertama, menciptakan kondisi yang mendorong dan mendukung usaha rakyat untuk memenuhi kebutuhan masyarakat dan memecahkan masalah yang dihadapi oleh masyarakat tersebut. Kedua, mengembangkan perangkat pemerintahan yang menunjang tingkat partisipasi masyarakat hingga unit pelayanan yang terkecil. Kemudian tujuan yang ketiga adalah mengembangkan sistem produksi untuk memenuhi tingkat swasembada di tingkat lokal ${ }^{1}$.

Ketiga tujuan tersebut tentunya tidak hanya mampu dijalankan pemerintahan daerah berdasarkan aspirasi dan prakarsa masyarakat saja, akan tetapi juga didukung melalui kebijakan strategis pemerintah pusat. Oleh karenanya dalam amanat Undang-

1 Hari Sabarno, 2007, Mandu Otonomi Daerah Menjaga Kesatuan Bangsa, Sinar Grafika, Jakarta, hlm, 43 
Undang Nomor 23 Tahun 2014 Tentang Pemerintah Daerah bagian Konsiderans ditegaskan pada poin c bahwa:

efisiensi dan efektivitas penyelenggaraan pemerintahan daerah perlu ditingkatkan dengan lebih memperhatikan aspek-aspek hubungan antara Pemerintah Pusat dengan daerah dan antardaerah, potensi dan keanekaragaman daerah, serta peluang dan tantangan persaingan global dalam kesatuan sistem penyelenggaraan pemerintahan negara;

Dalam aktualisasinya kemudian Undang-Undang Nomor 23 Tahun 2014 tentang Pemerintah Daerah mempertegas hubungan antara pemerintah pusat dan daerah tersebut secara hierarki yang di antaranya diatur dalam Pasal 251 yaitu :

(1) Perda Provinsi dan peraturan gubernur yang bertentangan dengan ketentuan peraturan perundang-undangan yang lebih tinggi, kepentingan umum, dan/atau kesusilaan dibatalkan oleh Menteri.

(2) Perda Kabupaten/Kota dan peraturan bupati/wali kota yang bertentangan dengan ketentuan peraturan perundang-undangan yang lebih tinggi, kepentingan umum, dan/atau kesusilaan dibatalkan oleh gubernur sebagai wakil Pemerintah Pusat.

Peran pemerintah pusat dalam hal ini bukan diartikan upaya intervensi pemerintahan pusat terhadap sistem otonomi yang dijalankan oleh pemerintah daerah, akan tetapi merupakan penjabaran lain dari falsafah sistem Negara kesatuan berbentuk republik yang telah ditegaskan dalam konstitusi. Melalui amanat pasal 251 diharapkan sistem pemerintahan daerah akan sinkron terhadap kebijakan yang secara nasional ingin dicapai oleh pemerintahan pusat.

Dalam implementasinya, pada tahun 2016 tidak tanggung-tanggung pemerintah pusat melalui Kementerian Dalam Negeri telah membatalkan 3.143 peraturan daerah. Pembatalan Perda tersebut menjadi polemik dalam kebijakan pemerintah daerah yang kemudian menggulirkan judicial review di Mahkamah Konstitusi atas Undang-Undang Nomor 23 Tahun 2014 tentang Pemerintah Daerah Pasal 251 yang diajukan oleh Asosiasi Pemerintah Kabupaten Seluruh Indonesia (APKASI) dan beberapa pemerintah kabupaten dan Kota.

Berdasarkan pada putusan Mahkamah Konstitusi Nomor 137/PUU-XIII/2015 secara singkat MK dalam putusannya membatalkan kewenangan pemerintah pusat yang tertuang dalam Pasal 251 Undang-Undang Nomor 23 Tahun 2014 Tentang Pemerintah Daerah. Pembatalan putusan tersebut tentunya menjadi persoalan sejauh mana kendali 
pemerintah pusat terhadap pelaksanaan pemerintah daerah pasca putusan MK tersebut dan bagaimana reposisi secara ideal yang perlu diterapkan dalam mekanisme review terhadap perundang-undangan ditingkat pemerintah daerah.

\section{METODE PENELITIAN}

Pendekatan yang digunakan dalam penelitian adalah yuridis normatif. Penelitian yuridis normatif menekankan pengkajian terkait asas-asas, doktrin yang bersifat normatif. Sedangkan spesifikasi penelitian yang digunakan dalam penelitian ini adalah deskriptif analitis, penggunaan deskriptif diharapkan dapat memberikan gambaran secara umum dan menyeluruh tentang objek yang diteliti, suatu penelitian deskriptif dimaksudkan untuk memberikan data yang seteliti mungkin tentang manusia, keadaan dan gejala-gejala lainnya. $^{2}$

Melalui pendekatan juridis normatif maka penelitian menggunakan data sekunder yang terdiri dari bahan hukum primer, bahan hukum sekunder dan bahan hukum tertier. Untuk menganalisis bahan-bahan tersebut metode yang digunakan adalah analisis secara kualitatif yang nantinya memungkinkan melalui proses a. mencatat yang menghasilkan catatan lapangan, dengan hal itu diberi kode agar sumber datanya tetap ditelusuri, b. Mengumpulkan, memilah, mengklasifikasikan, menyintesiskan, membuat ikhtisar dan membuat indeksnya dan c. berpikir, dengan jalan membuat agar kategori data itu mempunyai makna, mencari dan menemukan pola dan hubungan-hubungan, dan temuantemuan umum ${ }^{3}$.

\section{ANALISIS DAN PEMBAHASAN}

Dalam praktik pembangunan pemerintah daerah, desentralisasi memiliki pandangan bahwa sebagai sarana perubahan wujud pemerintah daerah yang partisipatif. Desentralisasi sebagai salah satu sarana dalam usaha melaksanakan pembangunan nasional (pembangunan ekonomi), TMH Lumban Tobing mengemukakan hal-hal sebagai berikut.

1. Program desentralisasi merupakan suatu metode yang efektif mendisversikan atau menyebarkan secara geografis decision making power ke daerah-daerah demi memperkokoh kesatuan dan ketahanan nasional.

2 Soerjono Soekanto, 1981, Pengantar Penelitian Hukum, UI Press, Jakarta, hlm 10

3 Lexi J. Moleong, 2007, Metodologi Penelitian Kualitatif, Rosda, Bandung, hlm. 248. 
2. Selain itu program desentralisasi yang lebih luas merupakan suatu metode untuk lebih menyesuaikan pembangunan nasional terhadap aspirasi dan potensi yang terdapat di daerah-daerah, yang seharusnya perlu dimanfaatkan demi mengamalkan prinsip Bhinneka Tungga Ika dalam kesatuan dan ketahanan nasional.

3. Program desentralisasi akan mengurangi beban dan campur tangan pemerintah pusat dalam masalah-masalah kecil pada tingkat daerah.

4. Program desentralisasi akan menghasilkan kesempatan-kesempatan dan kemungkinan koordinasi yang lebih baik antara kegiatan-kegiatan pembangunan oleh pemerintah pusat dan pemerintah daerah pada tingkat daerah, sehingga kemungkinan duplikasi dan benturan-benturan, pelaksanaan dan pembiayaan proyek dapat dihindari. Selain itu, penentuan lokasi yang tepat dari proyek pembangunan dapat lebih terjamin.

5. Program desentralisasi dapat mempertumbuhkan gairah dari daerah-daerah untuk membangun daerahnya sekuat tenaga

6. Program desentralisasi akan meningkatkan pengertian, partisipasi, dan dukungan masyarakat dalam pembangunan nasional ${ }^{4}$.

Ide dasar desentralisasi tersebut kemudian dituangkan dalam undang-undang pemerintahan daerah di antaranya adalah Undang-Undang Nomor 23 tahun 2014 yang telah mengalami perubahan. Konsep desentralisasi dianggap telah sesuai dengan cara pandang berlangsungnya demokrasi kedaerahan dimana masyarakat daerah memiliki keterlibatan dalam menentukan masa depan daerahnya.

Melalui adanya otonomi daerah, secara otomatis daerah dituntut lebih mandiri dalam mengurus rumah tangganya sendiri, dan ketergantungan terhadap pemerintah pusat sedikit demi sedikit terus dikurangi. Proses pemandirian ini sekaligus merupakan pemberdayaan bagi sumber daya manusia di daerah. Dalam konteks ini, sumber daya manusia (SDM) menempati posisi strategis dalam mengartikulasikan substansi kebijakan otonomi daerah untuk dikonkretisasi dalam sikap tindak dan perilaku yang nyata dalam setiap aktivitas kehidupan pemerintah daerah. Artikulasi dimaksud adalah strategi penyiapan SDM untuk implementasi otonomi daerah agar dambaan masyarakat akan kesejahteraan dan kemakmuran dapat dicapai secara optimal. Dambaan ini hanya dapat

4 Sutedi Andrian, 2009, Implikasi Hukum Atas Sumber Pembiayaan Daerah Dalam Kerangka Otonomi Daerah, Jakarta, Sinargrafika, hlm 21 
dicapai jika SDM memiliki pengetahuan dan keterampilan untuk mengelola dan mengolah kekuatan yang dimilikinya (sumber yang tersedia), memanfaatkan berbagai peluang, mengatasi kelemahan dan ancaman yang dihadapinya dengan etos membangun, kerja keras, jujur, kreatif profesional dan inovatif. Secara keseluruhan, pemberdayaan SDM dalam rangka otonomi bukan saja bermakna meningkatkan kapasitas (capacity building), tetapi juga akuntabilitas (accountability) SDM dalam arti yang luas ${ }^{5}$.

Di sini jelas bahwa Pemerintah Daerah berhak dan berkewajiban mengatur dan mengurus rumah tangga Daerahnya. Dengan tidak mengurangi ketentuan dimaksud dalam Undang-undang pembentukan Daerah sebagai pangkal ditetapkan urusan-urusan yang termasuk rumah tangganya disertai alat perlengkapan dan pembiayaannya serta sumbersumber pendapatan yang pertama dari Daerah itu ${ }^{6}$.

Hal yang perlu diperhatikan kemudian dalam konteks negara kesatuan penerapan asas sentralisasi dan desentralisasi dalam organisasi negara bangsa tidak bersifat dikotomi melainkan kontinum. Artinya pemerintah pusat tidak mungkin menyelenggarakan semua urusan pemerintahan ditangannya secara sentralisasi atau sebaliknya pemerintah daerah sepenuhnya menyelenggarakan semua urusan pemerintahan yang diserahkan. Yang bisa dilakukan adalah, selalu terdapat sejumlah urusan pemerintahan yang sepenuhnya diselenggarakan secara sentralisasi beserta penghalusannya, dekonsentrasi. Tidak pernah terdapat suatu urusan pemerintahan apa pun yang diselenggarakan sepenuhnya secara desentralisasi. Urusan pemerintah yang menyangkut kepentingan dan kelangsungan hidup berbangsa dan bernegara lazimnya diselenggarakan secara sentralisasi dan dekonsentrasi sedangkan urusan yang mengandung dan menyangkut kepentingan masyarakat setempat diselenggarakan secara desentralisasi ${ }^{7}$.

Berdasarkan pandangan tersebut maka substansi Undang-Undang Nomor 23 tahun 2014 tentang pemerintahan daerah telah memberikan kewenangan kepada pusat untuk mengharmonisasikan peraturan yang dibuat oleh pemerintah daerah. Hal ini diatur dalam Pasal 251. Dalam praktiknya hal tersebut kemudian kewenangan eksekutif dalam melakukan eksekutif review dibatalkan oleh Mahkamah Konstitusi yang dalam pasal 251

\footnotetext{
Hari Sabarno, Opcit, hlm 161

C.S.T Kansil, 1984, Pokok-pokok pemerintahan daerah, Jakarta, aksara baru, hlm 110

Sirajuddin dan Winardi, 2015, Hukum Tata Negara Indonesia, Setara Press (Kelompok Instras Publising), Malang, hlm 333
} 
diberikan kewenangan pemerintah pusat akan tetapi kemudian oleh Mahkamah Konstitusi diberikan kepada Mahkamah Agung.

Berdasarkan segi bentuk-bentuk strukturalnya organ-organ atau kelembagaan yang diberi tugas dan kewenangan untuk melakukan pengujian itu, kita dapat menemukan beragam pengalaman praktik di berbagai negara yang berbeda-beda antara satu sama lain. Berbagai keragaman pengalaman yang berkembang di berbagai negara itu dapat ditemukan benang merahnya berupa prinsip-prinsip yang berlaku umum di semua negara atau setidaknya di kebanyakan negara yang diteliti. Ide pengujian konstitusional (constitutional review) ini telah demikian luas diterima dan dipraktikkan di dunia sebagai hasil perkembangan ketatanegaraan di masing-masing negara. Oleh karena itu, perkembangannya di tiap-tiap negara berbeda-beda satu sama lain. Jelasnya, bahwa adalah bahwa tradisi penegakan konstitusi sebagai 'barometer' penyelenggaraan kegiatan bernegara di dunia terus berkembang luas, dan semakin diakui pula bahwa ide pengujian konstitusional (constitutional review) itu memang diperlukan dalam rangka melindungi dan mengawal pelaksanaan hukum dan konstitusi dalam praktik sehari-hari. Dalam perjalanan sejarahnya, sistem pengujian konstitusional (constitutional review) ini telah tumbuh sedemikian rupa melalui tahap-tahap perkembangan. ${ }^{8}$

Doktrin judicial review sangatlah penting demi terwujudnya sistem pemerintahan yang sesuai dengan prinsip Negara hukum. Jimly Asshiddiqie menyebutkan bahwa paling tidak ada 11 prinsip pokok yang terkandung dalam negara hukum yang demokratis, yakni: (i) adanya jaminan persamaan dan kesetaraan dalam kehidupan bersama; (ii) pengakuan dan penghormatan terhadap perbedaan/pluralitas; (iii) adanya aturan yang mengikat dan dijadikan sumber rujukan bersama; (iv) adanya mekanisme penyelesaian sengketa berdasarkan mekanisme aturan yang ditaati bersama itu; (v) pengakuan dan penghormatan terhadap HAM; (vi) pembatasan kekuasaan melalui mekanisme pemisahan dan pembagian kekuasaan disertai mekanisme penyelesaian sengketa ketatanegaraan antar lembaga negara baik secara vertikal maupun horizontal; (vii) adanya peradilan yang bersifat independen dan tidak memihak dengan kewibawaan putusan tertinggi atas dasar keadilan dan kebenaran; (viii) dibentuknya lembaga peradilan yang khusus untuk menjamin keadilan bagi warga negara yang dirugikan akibat putusan atau kebijakan pemerintahan (pejabat administrasi negara);(ix) adanya mekanisme 'judiciel review' oleh

8 Jimly Asshiddiqie, 2010, Model-Model Pengujian Konstitusional di Berbagai Negara, Sinar Grafika, Jakarta, hlm 9 
lembaga peradilan terhadap norma-norma ketentuan legislatif baik yang ditetapkan oleh lembaga legislatif maupun eksekutif; dan (xi) pengakuan terhadap asas legalitas atau 'due process of law' dalam keseluruhan sistem penyelenggaraan negara9.

Dalam pandangan Jimly, mekanisme judiciel review dijalankan oleh lembaga peradilan yang secara objektif menguji norma-norma yang dibentuk oleh eksekutif maupun legislatif. Namun tentunya dalam sistem pemerintahan daerah dimana komposisinya terdiri dari pemerintahan pusat dan daerah, maka pengujian tidak hanya secara substansi pada pengujian norma-norma, akan tetapi juga berkaitan dengan harmonisasi dan sinkronisasi aturan pemerintah pusat dan daerah.

Baik Kepala Daerah dan DPRD harus menyadari pada dasarnya kekuasaan mereka bersumber pada satu titik yang sama, yaitu kekuasaan eksekutif di tingkat pusat. Berkaitan dengan ini, harus dipahami dengan baik mengenai konsep central division of power dan area division of power. Central Division Of Power merupakan pembagian kekuasaan secara pokok yang terdiri dari kekuasaan eksekutif, legislatif dan yudikatif. Adapun area division of power (ADP) adalah pembagian kekuasaan berdasarkan wilayah-wilayah yang lebih kecil dalam wilayah nasional negara. Apabila ketiga kekuasaan CDP di distribusikan pada masing-masing ADP yang ada, maka yang terbentuk adalah negara bagian. Adapun apabila kekuasaan yang di distribusikan dari CDP kepada ADP hanya satu saja, maka yang terbentuk adalah otonom/pemerintah daerah (local government) ${ }^{10}$.

Pada sisi lain, posisi dari kekuasaan kehakiman menurut Tokyo Principles adalah (a) untuk menjamin agar setiap orang dapat hidup aman di bawah hukum, (b) mempromosikan, dalam batas-batas fungsi yudisial, suatu perlindungan hak asasi manusia dalam masyarakatnya; dan (c) untuk menjalankan hukum secara imparsial antara warga negara dengan warga negara dan antara warga negara dengan negara11. Berdasarkan atas komposisi tersebut maka sudah seharusnya bentuk dan desain apabila berkaitan dengan pembentukan perundang-undangan daerah tentunya harus mengombinasikan antara kekuasaan judicial dan eksekutif.

Memang jika dilihat dari optik nilai konstitusi dalam Undang-Undang Dasar Negara Republik Indonesia pada Pasal 18 ayat 6 dengan menegaskan bahwa Pemerintahan daerah berhak menetapkan peraturan daerah dan peraturan-peraturan lain untuk melaksanakan otonomi dan tugas pembantuan. Kewenangan tersebut jika ditempatkan pada konstitusi

$9 \quad$ Sirajuddin dan Winardi, Opcit, hlm 282-283

10 Hari sabarno, Lo'cit, hlm 85-86

${ }^{11}$ Sirajuddin dan Winardi, Lo'cit, hlm140 
tertulis tentunya sangat memiliki legitimasi yang tinggi, dibandingkan dengan diatur dalam undang-undang. Seperti halnya yang diatur dalam pembatalan perda yaitu yang dituangkan dalam Undang-Undang Nomor 23 tahun 2014 tentang Pemerintahan Daerah.

Namun tentunya, dengan konsep Negara kesatuan yang berbentuk Republik menjadi salah satu pertimbangan dimana legitimasi kekuasaan pemerintah daerah bukan semata-mata menjalankan keleluasaan dan kebebasan mengkreasikan sistem pemerintahan daerah, akan tetapi harus sinkron dan harmonis dengan pemerintahan pusat. Di sini jelas nilai pemberlakuan konstitusi tidak hanya normatif, akan tetapi juga memiliki nilai-nilai filosofis dalam penyelenggaraan Negara.

Putusan Mahkamah Konstitusi Nomor 137/PUU-XIII/2015 melihat bahwa pembatalan Perda yang dijalankan oleh pemerintah pusat telah jelas-jelas merugikan secara konstitusional kewenangan Pemerintah Daerah dalam membentuk Perda. Pada sisi lain kewenangan pemerintah daerah dalam menjalankan asas otonomi daerah tidak maksimal, hal ini didasarkan pada Perda yang dimiliki sebagai instrumen hukum legalitas otonomi daerah dibatalkan secara mudah melalui kewenangan pemerintah pusat.

Jika ditinjau, secara normatif maka tampak bahwa Mahkamah Konstitusi dalam membatalkan Peraturan daerah melalui putusan Nomor 137/PUU-XIII/2015 hanya berlandaskan norma perundang-undangan saja, baik yang tertuang dalam UndangUndang Dasar maupun dalam kewenangan juridis normatif terhadap kedudukan implementasi asas otonomi daerah. Padahal dalam praktiknya norma konstitusi tidak hanya terbentuk melalui sebuah skenario legalitas perundang-undangan, akan tetapi juga legalitas filosofis dan sosiologis hukum.

Di sinilah perlu adanya reposisi dalam proses judicial review peraturan daerah tidak hanya menjadi beban oleh Mahkamah Agung saja sebagaimana amar putusan MK Nomor 137/PUU-XIII/2015 akan tetapi juga dibebankan oleh eksekutif dalam menjalakan proses sinkronisasi dan harmonisasi kebijakan perundang-undangan. Model reposisi demikian tentunya sangat tepat dimana sistem filosofis dalam membangunkan Negara adalah melalui konsep gotong royong dan semangat kebersamaan dalam menjalankan kegiatan berbangsa dan bernegara.

Hal yang penting sebenarnya melalui reposisi tersebut memungkinkan konsep Negara hukum dijalankan secara sah dan legal. Dalam paham negara hukum yang demikian, harus dibuat jaminan bahwa hukum itu sendiri dibangun dan ditegakkan menurut prinsip-prinsip demokrasi. Oleh karena itu, prinsip supremasi hukum dan 
kedaulatan hukum itu sendiri, pada dasarnya berasal dan kedaulatan rakyat. Oleh sebab itu, prinsip negara hukum hendaklah dibangun dan dikembangkan menurut prinsipprinsip demokrasi atau kedaulatan rakyat (demokratische recht sstaat). Hukum tidak boleh dibuat, ditetapkan, ditafsirkan, dan ditegakkan dengan tangan besi berdasarkan kekuasaan belaka (machtsstaat). Prinsip negara hukum tidak boleh ditegakkan dengan mengabaikan prinsip-prinsip demokrasi yang diatur dalam Undang-Undang Dasar. Oleh karena itu, perlu ditegaskan pula bahwa kedaulatan berada di tangan rakyat yang diberlakukan menurut Undang-Undang Dasar (constitutional democracy) yang diimbangi dengan penegasan bahwa negara Indonesia adalah negara hukum yang berkedaulatan rakyat atau demokratis (democratische rechtsscaat) ${ }^{12}$.

Demokratis dan berkedaulatan ditemukan melalui kedudukan eksekutif dan yudikatif dalam melakukan review. Desain yang demikian tentunya sangat memaknai kedudukan konstitusi sebagai norma dasar mengingat dalam konstitusi, aspek demokratis dan berkedaulatan memiliki keabsahan dalam menjalankan kekuasaan pemerintah secara sah oleh lembaga-lembaga Negara yang diberi kewenangan sesuai dengan amanat Undang-Undang Dasar Negara Republik Indonesia tahun 1945.

\section{KESIMPULAN}

Paradigma pembangunan pemerintah tidak hanya memuat sifat asas otonomi daerah menjadi salah satu instrumen yang berdiri sendiri untuk menjadi acuan pelaksanaan otonomi daerah. Keterlibatan pemerintah pusat dalam mengharmonisasikan dan menyinkronisasikan orientasi pemerintahan daerah tentunya sangat tepat untuk menjadi pertimbangan sesuai dengan prinsip Negara kesatuan berbentuk republik.

Dalam praktiknya kemudian kewenangan pembatalan peraturan daerah sudah seidealnya memosisikan antara kekuasaan yudisial oleh mahkamah agung dan eksekutif dalam me-review peraturan perundang-undangan sehingga nantinya dapat menjadikan upaya harmonisasi dan sinkronisasi tidak dipisahkan substansi keadilan dan kepastian hukum yang diberikan kewenangan oleh Mahkamah Agung dalam menjalankan peran dan fungsinya dalam menegakkan hukum.

\footnotetext{
12 Ni'matul Huda, 2015, Hukum Tata Negara Indonesia, Raja Grafindo Persada, Jakarta, hlm 88-89
} 


\section{Daftar Pustaka}

Andrian, Sutedi, Implikasi Hukum Atas Sumber Pembiayaan Daerah Dalam Kerangka Otonomi Daerah, Jakarta: Sinar Grafika 2009.

Asshiddiqie, Jimly, Model-Model Pengujian Konstitusional di Berbagai Negara, Jakarta: Sinar Grafika, 2010.

Huda, Ni'matul, Hukum Tata Negara Indonesia, Jakarta: Raja Grafindo Persada 2015.

Kansil, C.S.T Kansil, Pokok-pokok Pemerintahan Daerah, Jakarta: Aksara Baru 1984.

Moleong, Lexi J., Metodologi Penelitian Kualitatif, Bandung: Rosda 2007.

Sabarno, Hari, Mandu Otonomi Daerah Menjaga Kesatuan Bangsa, Jakarta: Sinar Grafika 2007.

Sirajuddin dan Winardi, Hukum Tata Negara Indonesia, Malang: Setara Press (Kelompok Instras Publising) 2015.

Soekanto, Soerjono, Pengantar Penelitian Hukum, Jakarta: UI Press 1981. 